\title{
Constraints on the evolution of disease resistance in an annual legume
}

\author{
MATTHEW A. PARKER \\ Department of Biological Sciences, State University of New York, Binghamton, New York 13902-6000 U.S.A.
}

\begin{abstract}
An extensive survey of variation in disease resistance within one population of the annual legume Amphicarpaea bracteata revealed that only 11 per cent of the plants were resistant toward one native isolate of the pathogen Synchytrium decipiens. All plants completely lacked resistance toward two other native pathogen isolates. However, strong resistance to these pathogens was found among $A$. bracteata genotypes in nearby populations. These results imply that limits on the input of new resistance genes into local populations due to spatially-restricted gene flow may be a basic constraint on the evolution of disease resistance in this plant.
\end{abstract}

Keywords: coevolution, disease resistance, gene flow, pathogens, polymorphism.

\section{Introduction}

Biologists have voiced many opinions about what constraints are most important in preventing organisms from evolving improved resistance to their pathogens. According to one major viewpoint, constraints arise from the fact that host genes conferring resistance have harmful pleiotropic effects (Van der Plank, 1975; Harlan, 1976), so that the highest overall fitness is not achieved by individuals with maximum resistance. In this case, resistance should evolve to the point where benefits from limiting pathogen attack are balanced by these fitness costs (Rhoades, 1979; Fagerstrom, 1989). However, factors other than selective trade-offs of this sort may also lead to constraints on disease resistance in natural populations (Parker, 1992a). Genetic drift or population bottlenecks (O'Brien \& Evermann, 1988) may result in genetically uniform host populations that are incapable of responding to selection for increased resistance. Factors that restrict genetic recombination, such as extreme inbreeding (Parker, 1991b) or asexual reproduction, may also result in important evolutionary constraints, by facilitating pathogen adaptation to overcome defences of particular host lineages (Hamilton, 1982; Tooby, 1982).

In this study, I examine the nature of constraints on adaptation by the annual legume Amphicarpaea bracteata to its host-specific pathogen Synchytrium decipiens (Chytridiomycota). Heavy $S$. decipiens infection can increase juvenile plant mortality and reduce seed production (Parker, 1986; Schnee \& Waller,
1986). Improved resistance toward S. decipiens would thus seem to be beneficial for plants. However, local populations of $A$. bracteata are often dominated by susceptible genotypes (Parker, 1985, 1991a).

In two previous studies of $A$. bracteata, I have examined the theory that evolution of resistance is constrained by harmful pleiotropic effects of disease resistance genes (Parker, 1990; Parker \& Wilkens, 1990). The fitness of resistant and susceptible plant genotypes was compared in several pathogen-free environments that differed widely in the extent of intra- and interspecific plant competition, including greenhouse, garden, and natural habitats. There was no evidence in any of these experiments that alleles for disease resistance caused plants to have inferior fitness in the absence of pathogens (Parker, 1990; Parker \& Wilkens, 1990). In the following study, I have therefore focused on alternatives to the theory that constraints on resistance are due to fitness costs associated with resistance genes.

A. bracteata reproduces primarily by self-fertilization, which limits the opportunity for pollen-mediated gene flow, and allows local proliferation of single homozygous genotypes. Hence, selfing populations may come to be dominated by numerous genetically similar individuals (Wright, 1946; Stebbins, 1957). Extreme inbreeding may thus be associated with a reduction in the local diversity of host genotypes on which selection can act. In order to test the hypothesis that plants within local populations lacked suitable genetic variation that would permit them to evolve 
improved resistance to pathogens, I analysed the disease resistance of a large sample of plant genotypes at one site. Plants from two nearby populations were also examined, to determine whether gene flow from adjacent areas could potentially be a source of new resistance genes for improving adaptation by plants to pathogens. These experiments indicated that constraints on disease resistance cannot be understood solely in terms of forces acting within a single local population. Instead, evolutionary processes at the metapopulation level (Burdon et al., 1990) appear to be critical.

\section{Materials and methods}

Amphicarpaea bracteata (hogpeanut) is an annual legume that grows in a variety of partially shaded habitats in eastern North America. In most populations, $>99$ per cent of seeds develop from obligately self-pollinated cleistogamous flowers, so $A$. bracteata populations tend to be highly inbred (Parker, 1986; Schnee \& Waller, 1986). The host-specific pathogen Synchytrium decipiens (Chytridiomycota) attacks the leaves, stems and fruits of $A$. bracteata. This pathogen appears to be completely asexual (Karling, 1964). It has a water-borne infective stage that penetrates a single host cell, which then enlarges to form an orange sorus. Within approximately 3 weeks of infection, sori burst open to release progeny sporangia. Under favourable weather conditions, the pathogen reproduces continuously, and can cause severe damage to plants, including premature leaf abscission, stem deformities, and death of meristems. When abundant, it can significantly reduce the reproductive success of its host (Parker, 1986; Schnee \& Waller, 1986). As is true for all foliar pathogens, the density of $S$. decipiens varies considerably from year to year, due to weather, changes in host abundance, and other factors. In some years, severe disease has been widespread at the site examined in this study, with no plants escaping infection (Parker, $1985,1986)$. In other years, pathogens have attacked only a small fraction of the plant population (personal observations). Thus, natural selection on plants for disease resistance is likely to be an intermittent process. The dispersal capacity of $S$. decipiens appears to be rather limited compared to many foliar pathogens. For example, susceptible plants transplanted $30 \mathrm{~m}$ from an abundantly infected natural population remained completely free of infection for several months (Parker, 1991a).

A. bracteata plants were collected at three sites $10 \mathrm{~m}$ apart along a transect through a population at Lake Defiance, Illinois (the 'LD' population described in Parker, 1985, 1986). At each site, one cleistogamous seed was collected from each of 22 to 30 different plants. Sampling occurred after plant senescence in October, and was therefore random with respect to parental disease resistance phenotype. Seeds were grown in a greenhouse to obtain selfed progeny seeds for measuring disease resistance. Out of 75 seeds initially sampled, 57 produced selfed progenies of sufficient size to use for inoculation experiments.

One pathogen isolate was collected from each of the same three sites where plants were sampled, and a standard laboratory inoculation procedure was used to test the response of each of the 57 seed families to each pathogen isolate. This involved placing seedlings of a standard developmental stage in an aqueous suspension of pathogen zoospores for $12 \mathrm{~h}$ (Parker, 1985). A mean of 23 seedlings was inoculated per family per isolate (range, 6 to 48), for a total of 3913 seedlings tested. I recorded the fraction of plants that became infected with each isolate, and estimated the frequency of pathogen developmental failure on each family by examining 400 sori 25 days after inoculation ( 40 per leaf on each of 10 leaves per family). Sori were classified into one of two states: healthy (large and full of progeny spores) or aborted (shriveled and lacking spores). The fraction of sori that reproduce successfully is a basic indicator of plant susceptibility to a given pathogen (Parker, 1991a, b).

To examine whether plants in nearby populations had any resistance to pathogens native to the LD site, plants from two adjacent areas were also inoculated with the same $S$. decipiens isolates. Twelve plants were sampled from the nearest disjunct population of $A$. bracteata ( $96 \mathrm{~m}$ away from the LD site), and 10 were sampled from a population $1 \mathrm{~km}$ away. There was little or no $A$. bracteata present at distances intermediate between $96 \mathrm{~m}$ and $1 \mathrm{~km}$, because most of this region contains a wetland habitat unsuitable for $A$. bracteata. A mean of 23 selfed progeny seedlings was inoculated per family per isolate (range, 7 to 68 ), for a total of 1506 seedlings tested.

\section{Results}

All LD plant families tested were highly vulnerable to infection with the three pathogen isolates from their native habitat, with an overall infection frequency of more than 96 per cent (range among isolates, 94-98 per cent). However, plants displayed wide variation in resistance to pathogen reproduction in some cases (Fig. 1). On six plant families, nearly all sori of Isolate $B$ died (mean proportion of sori with progeny spores $<5$ per cent). In a previous study, variation in resistance to this isolate was found to be controlled by a single locus, with resistance exhibiting nearly complete dominance 
(Parker, 1988). Five of the six plant families with resistance to Isolate B came from the same local site within the population where the isolate was collected.

No heterogeneity in disease resistance phenotype was observed among individuals within any of the 57 plant families tested. This apparently high degree of homozygosity is not surprising given the substantial level of inbreeding in this population (Parker, 1986)

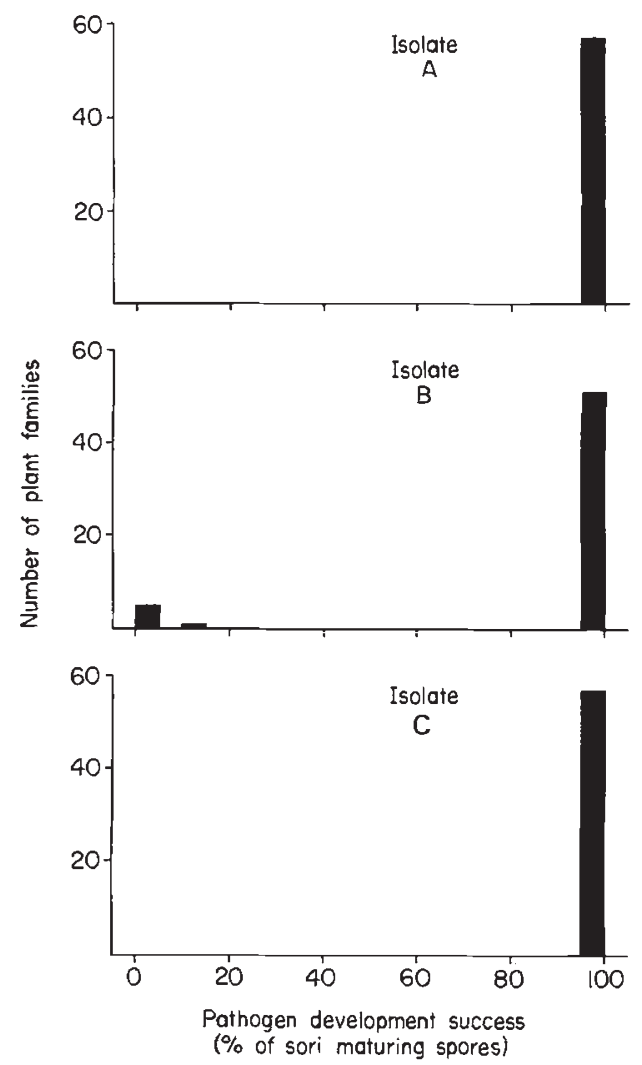

Fig. 1 Distribution of disease reaction phenotypes for $57 \mathrm{~A}$. bracteata plant families, each inoculated with three native isolates of the pathogen Synchytrium decipiens. and the fact that each plant family came from a selffertilized cleistogamous seed.

Despite the presence of resistance at low frequency toward one pathogen isolate, all plants in this population were uniformly susceptible toward the two other isolates tested (Fig. 1). Thus, the primary constraint on adaptation may simply be that appropriate genetic variation for disease resistance is not available among plants at this site. To study this issue, I examined whether plants in two nearby populations had any resistance toward LD pathogens (Table 1). All plants tested from the nearest population were uniformly susceptible to all three LD pathogen isolates. The phenotype of these plants was identical to the dominant phenotype among plants native to the LD site (Fig. 1), with very high infection rates, and nearly 100 per cent pathogen development success on all plants. In the population 1 $\mathrm{km}$ away, two distinct phenotypes were present, designated I and II. Two families proved to be completely susceptible to LD pathogens, as in the most common phenotype among plants at the LD site (phenotype I). However, eight families were totally immune to infection with all three $\mathrm{LD}$ pathogen isolates (phenotype II). These plants exhibited no visible disease symptoms when inoculated with LD pathogens. This broad immunity contrasts with the narrow resistance (toward one out of three isolates) that occurred as a polymorphism within the LD population (Fig. 1).

\section{Discussion}

In a previous study, variation in plant resistance to $S$. decipiens Isolate $\mathrm{B}$ was found to be controlled by alleles at a single locus (Parker, 1988). The evolutionary processes responsible for the polymorphism of this trait at the LD site remain unclear. Most theoretical discussions of host-pathogen coevolution have argued that natural selection should almost inevitably lead to

Table 1 Disease reaction phenotypes toward LD pathogens among A. bracteata plants from adjacent populations

\begin{tabular}{|c|c|c|c|c|c|c|c|c|c|}
\hline \multirow[b]{3}{*}{$\begin{array}{l}\text { Pathogen } \\
\text { isolate }\end{array}$} & \multicolumn{9}{|c|}{ Source of plants (distance from LD site) } \\
\hline & \multicolumn{3}{|c|}{$96 \mathrm{~m}$} & \multicolumn{3}{|c|}{$1 \mathrm{~km}$ - phenotype I } & \multicolumn{3}{|c|}{$1 \mathrm{~km}$ - phenotype II } \\
\hline & $N^{*}$ & $\begin{array}{l}\text { Seedlings } \\
\text { infected } \\
(\%)\end{array}$ & $\begin{array}{l}\text { Pathogen } \\
\text { development } \\
\text { success }(\%)\end{array}$ & $N$ & $\begin{array}{l}\text { Seedlings } \\
\text { infected } \\
(\%)\end{array}$ & $\begin{array}{l}\text { Pathogen } \\
\text { development } \\
\text { success }(\%)\end{array}$ & $N$ & $\begin{array}{l}\text { Seedlings } \\
\text { infected } \\
(\%)\end{array}$ & $\begin{array}{l}\text { Pathogen } \\
\text { development } \\
\text { success }(\%)\end{array}$ \\
\hline A & 12 & 99 & 99 & 2 & 100 & 99 & 8 & 0 & - \\
\hline B & 12 & 99 & 99 & 2 & 100 & 99 & 8 & 0 & - \\
\hline C & 12 & 99 & 99 & 2 & 90 & 99 & 8 & 0 & - \\
\hline
\end{tabular}

*Plant families tested. 
polymorphism (Haldane, 1949; Person, 1966; Clarke, 1976; Levin et al., 1982; Tooby, 1982). However, it is questionable whether the LD polymorphism is maintained by any type of balancing selection. Plants carrying the allele for resistance to Isolate B can grow significantly better than susceptible plants in the presence of this pathogen (Parker, 1988). Yet other pathogen genotypes native to the LD population are completely unaffected by this resistance allele (Fig. 1). Isolates $\mathrm{A}$ and $\mathrm{C}$ had a mean development success rate of 98.9 per cent $( \pm 0.2$ per cent) on the six resistant host families, and had essentially identical success on the other 51 host families $(98.8 \pm 0.1$ per cent). If plants carrying the resistance allele should become common, this should cause natural selection on the pathogen population in favour of these widely virulent types. Thus, a change in the genetic composition of the local pathogen population could rapidly nullify any fitness advantage associated with this resistance allele. Indeed, if the pathogen population were to become fixed for genotypes of wide virulence like Isolates A and $C$, variation at this locus would become selectively neutral, since the allele for disease resistance has no measurable effect on plant fitness in the absence of pathogen attack (Parker, 1990; Parker \& Wilkens, 1990). The issue of whether variation among plants and pathogens in the $\mathrm{LD}$ population represents a balanced vs. a transient polymorphism can only be resolved by long-term studies of both species.

Regardless of the form of selection acting on resistant plants within the LD population, the current overall pattern at this site is one of virtually complete plant susceptibility to local pathogens. Negligible resistance to pathogen reproduction was found in 96 per cent $(165 / 171)$ of the host family/pathogen isolate combinations tested (Fig. 1). Nevertheless, plants with effective resistance to LD pathogens clearly occurred in nearby populations (Table 1). Furthermore, in a previous transplant study at the LD site, certain plants from both the $1 \mathrm{~km}$ population and from another population $100 \mathrm{~km}$ away displayed complete immunity when exposed in the field to LD pathogens, while native LD plants were highly susceptible (Parker, 1985). Thus, even though effective disease resistance is lacking within the LD population, genetic resources do exist in other populations of $A$. bracteata that would allow an improvement of adaptation to $\mathrm{LD}$ pathogens. These results imply that the primary constraint on disease resistance for this population does not involve fitness costs associated with resistance genes (Parker, 1990; Parker \& Wilkens, 1990), but rather, involves various processes (drift, inbreeding, and restricted migration) that limit the local diversity of genotypes on which selection can act. All other things being equal, an increase in gene flow distance should benefit plants in their coevolutionary conflict with pathogens, by increasing the rate of input of new resistance genes into local populations.

Analysis of migration in $A$. bracteata suggests that the normal rate of input of such genes will be very low. First, gene flow via pollen dispersal will be minimal, due to the high frequency of self-fertilization in $A$. bracteata. Long-distance flights by pollinators are possible (Ellstrand \& Marshall, 1985), but with a typical selfing rate in excess of 99 per cent, such rare long-distance pollen dispersal events will provide only a negligible contribution of new genetic material. Secondly, seed dispersal in $A$. bracteata is accomplished by explosive dehiscence of seed pods, which normally results in seed movement of less than $3 \mathrm{~m}$ (Trapp, 1988). Long-distance seed dispersal mediated by mammals or birds is again possible (Janzen, 1984), but should be a highly unusual event. Thus, limits on the input of new resistance genes as a result of restricted gene flow may be a primary constraint on adaptation by $A$. bracteata to local pathogens.

Furthermore, while migrant plants may often display effective resistance toward pathogens endemic to a new habitat (Parker, 1985, 1991a, 1992a), other selective factors may interfere with their establishment. First, migrants carrying new resistance genes may also have correlated traits that make them less well adapted to various other features of the new habitat (Parker, 1991b). Secondly, hybridization between divergent lineages in $A$. bracteata can result in substantial outbreeding depression, apparently due to the breakup of coadapted gene complexes (Parker, 1992b). Thus, even in cases where migration introduces new resistance genes into a local population, there are other selective constraints that may prevent them from spreading.

In any case, these results highlight the importance of looking at evolutionary processes on a regional scale, in order to interpret constraints on coevolution within local populations. A similar argument was made by Burdon et al. (1990), in discussing a host-pathogen system with a rather different population structure. Further comparative studies of a diversity of systems will be needed for a broad perspective regarding constraints on adaptation among coevolving species.

\section{Acknowledgements}

I am grateful to N. Muckova and R. Wilkens for help with laboratory and fieldwork, and to D. S. Wilson for comments on the manuscript. Financial support was provided by NSF grant BSR- 8717222 . 


\section{References}

BURDON, J. J., BROWN, A. H. D. AND JAROSZ, A. M. 1990. The spatial scale of genetic interaction in host-pathogen coevolved systems. In: Burdon, J. J. and Leather, S. R. (eds) Pests, Pathogens, and Plant Communities, Blackwell, Oxford, pp. 233-247.

ClARKE, B. 1976. The ecological genetics of host-parasite relationships. In: Taylor, A. E. R. and Muller, R. (eds) Genetic Aspects of Host-Parasite Relationships, Blackwell, London, pp. 87-103.

ELLSTRAND, N. C. AND MARSHALL, D. L. 1985. Interpopulation gene flow by pollen in wild radish, Raphanus sativus. Am. Nat., 126, 606-616.

FAGERSTROM, T. 1989. Anti-herbivory chemical defense in plants: a note on the concept of cost. Am. Nat., 133, 281-287.

HALDANE, J. B. S. 1949. Disease and evolution. La Ricerca Scientifica Supplemento, 19, 68-76.

HAMilTon, w. D. 1982. Pathogens as causes of genetic diversity in their host populations. In: Anderson, R. M. and May, R. M. (eds) Population Biology of Infectious Diseases, Springer, New York, pp. 269-296.

HARLAN, J. R. 1976. Diseases as a factor in plant evolution. Ann. Rev. Phytopathol., 14, 31-51.

JANZEN, D. H. 1984. Dispersal of small seeds by big herbivores: foliage is the fruit. Am. Natur, 123, 338-353.

KARLING, J. S. 1964. Synchytrium. Academic Press, New York. LEVIN, B. R., ALLISON, A. C., BREMERMANN, H. J., CAVALLI-SFORZA, L. L., CLARKE, B. C., FRENTZEL-BEYME, R., HAMILTON, W. D., LEVIN, S. A., MAY, R. M. AND THEIME, H. R. 1982. Evolution of parasites and hosts. In: Anderson, R. M. and May, R. M. (eds) Population Biology of Infectious Diseases, Springer, New York, pp. 213-243.

O'BRIEN, S. J. AND EVERMANN, J. F. 1988. Interactive influence of infectious disease and genetic diversity in natural populations. Trends Ecol. Evol., 3, 254-259.

PARKER, M. A. 1985. Local population differentiation for compatibility in an annual legume and its host-specific fungal pathogen. Evolution, 39, 713-723.

PARKER, M. A. 1986. Individual variation in pathogen attack and differential reproductive success in the annual legume Amphicarpaea bracteata. Oecologia, 69, 253-259.

PARKER, M. A. 1988. Polymorphism for disease resistance in the annual legume Amphicarpaea bracteata. Heredity, 60 , 27-31.

PARKER, M. A. 1990. The pleiotropy theory for polymorphism of disease resistance genes in plants. Evolution, 44, 1872-1875.

PARKER, M. A. 1991a. Local genetic differentiation for disease resistance in a selfing annual. Biol. J. Linn. Soc., 42, 337-349.

PARKER, M. A. 1991b. Nonadaptive evolution of disease resistance in an annual legume. Evolution, 45, 1209-1217.

PARKER, M. A. 1992a. Constraints on the evolution of resistance to pests and pathogens. In: Ayres, P. G. (ed.) Pests and Pathogens: Plant Responses to Foliar Attack, Bios Scientific Publishers, Oxford, pp. 181-197.

PARKER, M. A. 1992b. Outbreeding depression in a selfing annual. Evolution, 46, 837-841.

PARKER, M. A. AND WILKENS, R. T. 1990. Effects of disease resistance genes on Rhizobium symbiosis in an annual legume. Oecologia, 85, 137-141.

PERSON, C. 1966. Genetic polymorphism in parasitic systems. Nature, 212, 266-267.

RHOADES, D. F. 1979. Evolution of plant chemical defense against herbivores. In: Rosenthal, G. A. and Janzen, D. H. (eds) Herbivores: their Interaction with Secondary Plant Metabolites, Academic Press, New York, pp. 3-54.

SCHNEE, B. K. AND WALLER, D. M. 1986. Reproductive behavior of Amphicarpaea bracteata (Leguminosae), an amphicarpic annual. Am. J. Bot., 73, 376-386.

STEBBINS, G. L. 1957. Self fertilization and population variability in the higher plants. Am. Natur., 91, 337-354.

TOOBY, J. 1982. Pathogens, polymorphism, and the evolution of sex. J. Theor. Biol., 97, 557-576.

TRAPP, E. J. 1988. Dispersal of heteromorphic seeds in Amphicarpaea bracteata. Am. J. Bot., 75, 1535-1539.

VAN DER Plank, J. E. 1975. Principles of Plant Infection. Academic Press, New York.

WRIGHT, s. 1946. Isolation by distance under diverse systems of mating. Genetics, 31, 39-59. 